\title{
PENGARUH PENGETAHUAN KEBENCANAAN TERHADAP SIKAP KESIAPSIAGAAN DALAM MENGHADAPI BENCANA PADA MAHASISWA PROGRAM STUDI PENDIDIKAN GEOGRAFI UNIVERSITAS KANJURUHAN MALANG
}

\author{
${ }^{1)}$ Dwi Kurniawati; ${ }^{2}$ Suwito \\ ${ }^{122)}$ Universitas Kanjuruhan Malang \\ Email: ${ }^{1)}$ kurniawatid96@yahoo.co.id; ${ }^{2}$ Suwito@unikama.ac.id
}

\begin{abstract}
Abstrak
Pengetahuan merupakan faktor utama dan menjadi kunci untuk kesiapsiagaan. Pengetahuan yang dimiliki dapat mempengaruhi sikap dan kepedulian untuk siap siaga dalam mengantisipasi bencana. Pentingnya kesiapsiagaan merupakan salah satu elemen penting dari kegiatan pencegahan pengurangan risiko bencana yang bersifat pro-aktif sebelum terjadinya suatu bencana. Penting bagi mahasiswa program studi pendidikan geografi Universitas Kanjuruhan Malang memiliki pengetahuan kebencanaan serta kesiapan bencana yang baik. Tujuan penelitian ini antara lain: 1) Mengetahui tingkat pengeta-huan kebencanaan pada mahasiswa program studi pendidikan geografi Universitas Kanjuruhan Malang. 2) Mengetahui sikap kesiapsiagaan dalam menghadapi bencana pada mahasiswa program studi pendidikan geografi Universitas Kanjuruhan Malang. 3) Mengetahui pengaruh pengetahuan kebencanaan terhadap sikap kesiapsiagaan dalam menghadapi bencana pada mahasiswa program studi pendidikan geografi Universitas Kanjuruhan Malang. Rancangan penelitian ini menggunakan rancangan deskriptif kuantitatif. Desain penelitian cross sectional, yaitu hanya mengkaji masalah atau keadaan objek pada waktu penelitian berlangsung untuk melihat pengaruh tingkat pengetahuan kebencanaan terhadap sikap kesiapsiagaan mahasiswa. Proses pengumpulan dan pengukuran variable-variabelnya dilakukan pada waktu yang bersamaan. Populasi dalam penelitian ini adalah seluruh mahasiswa Prodi Pendidikan Geografi Universitas Kanjurahan Malang yang berjumlah 178. Teknik sampling dalam penelitian ini adalah Proportional random sampling, yakni sampel diambil $30 \%$ dari 178 mahasiswa sehingga diperoleh 53 mahasiswa. Berdasarkan hasil penelitian tingkat pengetahuan kebencanaan mahasiswa berada dikategori tinggi. Sikap kesiapsiagaan mahasiswa dalam menghadapi bencana berada dikategori sangat tinggi. Hasil pengujian hipotesis dengan uji t dan uji koefisien determinasi, maka ada pengaruh positif pengetahuan kebencanaan terhadap sikap kesiapsiagaan mahasiswa dalam menghadapi bencana. Hal ini berarti semakin tinggi pengetahuan kebencanaan maka akan semakin tinggi pula sikap kesiapsiagaan mahasiswa dalam menghadapi bencana.
\end{abstract}

Kata Kunci: Kebencanaan, pengetahuan, kesiapsiagaan, bencana.

\section{PENDAHULUAN}

Indonesia merupakan salah satu negara yang rawan mengalami bencana alam. Tahun 2005, International Strategy for Disaster Reduction 2006-2009, World Disaster Reduction Campaign dan UNESCO menetapkan Indonesia pada urutan ke-7 (tujuh) negara di dunia yang rawan bencana alam. Kondisi ini tidak terlepas dari letak Indonesia secara geologis yakni berada pada pertemuan dua lempeng besar Eurasia dan Indoaustralia. Akibat dari pertemuan kedua lempeng tersebut, Indonesia menjadi salah satu negara yang dilalui jalur Ring of Fire atau jalur cincin api sehingga Indonesia memiliki banyak gunung api serta seringnya terjadi gempa bumi. Sedangkan secara astronomi, Indonesia dilalui garis khatulistiwa sehingga beriklim tropis. Hal ini mengakibatkan curah hujan yang tinggi pada musim hujan dan 
kekeringan pada musim kemarau. Berdasarkan faktor-faktor tersebut, menjadikan Indonesia rawan terhadap bencana alam seperti gempa bumi, tsunami, gunung meletus, banjir, longsor, kekeringan, kebakaran hutan, angin puting beliung dan sebagainya.

Banyak kerugian yang telah disebabkan bencana baik harta maupun jiwa. Berdasarkan data BNPB selama tahun 2016 terdapat 2.342 kejadian bencana dan mengalami kenaikan $35 \%$ jika dibandingkan dengan jumlah bencana pada 2015. Data tersebut merupakan yang tertinggi sejak pencatatan kejadian bencana pada 2002. Dari jumlah tersebut, sebanyak $92 \%$ bencana hidrometeorologi yang didominasi oleh 766 banjir, 612 longsor, dan 669 puting beliung. Sedangkan $8 \%$ terdiri dari 178 kebakaran hutan dan lahan, 13 gempa, 7 gunung meletus, dan 23 gelombang pasang dan abrasi. Dampak yang timbulkan akibat bencana telah menyebabkan 522 orang meninggal dunia dan hilang, 3,05 juta jiwa mengungsi dan menderita, 69.287 unit rumah rusak dan 2.311 unit fasilitas umum rusak.

Kurangnya kesiapan masyarakat dalam menghadapi bencana merupakan salah satu faktor yang mengakibatkan risiko bencana menjadi besar. Hidayati (2006) memaparkan dalam upaya mengurangi risiko bencana, terdapat tiga pemangku kepentingan (stakeholder) yaitu individu dan rumah tangga, pemerintah serta komunitas sekolah. Individu dan rumah tangga merupakan subjek dan objek dari kesiapsiagaan karena berpengaruh secara langsung terhadap risiko bencana. Sedangkan pemerintah memiliki peran yang penting dalam mengupayakan ketersediaan kebutuhan masyarakat pada pra, saat dan pasca bencana. Sekolah merupakan stakeholder yang sangat berperan sebagai sumber pengetahuan dan menyebarluaskan pengetahuan bencana. Sekolah juga memiliki peran sebagai petunjuk praktis dalam penanggulangan becana baik pra, saat maupun pasca bencana.

Kondisi Indonesia yang rentan terhadap bencana seharusnya diimbangi dengan upaya peningkatan kesiapsiagaan bencana. Kesiapsiagaan bencana merupakan kepentingan semua individu dan semua institusi, termasuk di dalamnya institusi pendidikan. UU No. 24 Tahun 2007 tentang Penanggulangan Bencana menjelaskan, kesiapsiagaan adalah "serangkaian kegiatan yang dilakukan untuk mengantisipasi bencana melalui pengorganisasian serta melalui langkah yang tepat guna dan berdaya guna". Tujuan dilakukannya kesiapsiagaan bencana adalah untuk mengurangi risiko (dampak) yang diakibatkan oleh adanya bencana. Carter (dalam Hidayati, 2006) menjelaskan bahwa, kesiapsiagaan adalah "tindakan-tindakan yang memungkinkan pemerintah, organisasi, masyarakat, komunitas dan individu untuk mampu menanggapi suatu situasi bencana secara cepat dan tepat guna". Tindakan kesiapsiagaan juga meliputi penyusunan penanggulangan bencana, pemeliharaan sumber daya dan pelatihan personil.

Pengetahuan merupakan faktor utama dan menjadi kunci untuk kesiapsiagaan. Pengetahuan yang dimiliki dapat mempengaruhi sikap dan kepedulian untuk siap siaga dalam mengantisipasi bencana. Kesiapsiagaan merupakan salah satu bagian dari proses manajemen bencana dan di dalam konsep bencana yang berkembang saat ini. Pentingnya kesiapsiagaan merupakan salah satu elemen penting 
dari kegiatan pencegahan pengurangan risiko bencana yang bersifat pro- aktif sebelum terjadinya suatu bencana.

Peran pendidikan sangat berpengaruh terhadap terwujudnya kesiapsiagaan bencana. Clust, dkk (2007) mengatakan bahwa "fungsi edukasi sebagai salah satu media terbaik untuk mempersiapkan komunitas terhadap bencana". Pada pendidikan bencana, tingkat kesiapan individu akan didiskusikan yang kemudian ditingkatkan dalam pembelajaran. Kesiapan individu terhadap bencana juga ditunjukkan oleh adanya pengetahuan, keterampilan, dan kemampuan yang diperoleh melalui pembelajaran dari pengalaman yang diaplikasikan secara nyata saat kondisi darurat.

Mahasiswa sebagai agen of chance yang akan berperan sebagai edukator kesiapan bencana, siap diterjunkan kepada masyarakat, dan mampu memberikan intervensi yang tepat pada saat bencana terjadi. Oleh karena itu penting bagi mahasiswa program studi pendidikan geografi Universitas Kanjuruhan Malang memiliki pengetahuan kebencanaan serta kesiapan bencana yang baik. Pendidikan kebencanaan telah terintegrasi di program studi pendidikan geografi sebagai mata kuliah Geografi Bencana yang akan ditempuh mahasiswa pada semester enam.

Mahasiswa yang menempuh mata kuliah geografi bencana diharapkan mampu mengidentifikasi jenis-jenis bencana, penyebab terjadinya bencana, potensi kebencanaan, pemetaan wilayah resiko bencana, mitigasi bencana, dan rehabilitasi wilayah yang terkena bencana. Pada penelitian ini akan dilakukan pada mahasiswa program studi pendidikan geografi Universitas Kanjuruhan Malang angkatan 2014 yang belum menempuh mata kuliah geografi bencana. Hal ini bertujuan untuk mengetahui seberapa besar tingkat pengetahuan dan kesiapsiaagaan mahasiswa sebelum menempuh mata kuliah geografi bencana. Berdasarkan latar belakang tersebut maka dilakukanlah penelitian "Pengaruh Pengetahuan Kebencanaan terhadap Sikap Kesiapsiagaan dalam Menghadapi Bencana Pada Mahasiswa Program Studi Pendidikan Geografi Universitas Kanjuruhan Malang".

\section{METODE PENELITIAN}

Rancangan penelitian ini menggunakan rancangan deskriptif kuantitatif. Desain penelitian cross sectional, yaitu hanya mengkaji masalah atau keadaan objek pada waktu penelitian berlangsung untuk melihat pengaruh tingkat pengetahuan kebencanaan terhadap sikap kesiapsiagaan mahasiswa. Proses pengumpulan dan pengukuran variablevariabelnya dilakukan pada waktu yang bersamaan. Variabel dalam penelitian ini yaitu, tingkat pengetahuan kebencanaan (X) sebagai variabel bebas dan sikap kesiapsiagaan (Y) sebagai variabel terikat.

Populasi dalam penelitian ini adalah seluruh mahasiswa program studi pendidikan geografi Universitas Kanjuruhan Malang Angkatan 2014 tahun ajaran 2016/2017 yang berjumlah lima kelas yaitu kelas 2014A sampai 2014E dengan jumlah keseluruhan 178. Berikut rincian jumlah tiap kelas mahasiswa angkatan 2014 tahun ajaran 2016/2017 program studi pendidikan geografi Universitas Kanjuruhan Malang: 
Tabel 1 Populasi Penelitian

\begin{tabular}{cc}
\hline Angkatan 2014 & Jumlah \\
\hline Kelas A & 35 \\
Kelas B & 35 \\
Kelas C & 36 \\
Kelas D & 36 \\
Kelas E & 36 \\
\hline Jumlah Populasi & $\mathbf{1 7 8}$
\end{tabular}

Sumber: Data Prodi Pendidikan Geografi Universitas Kanjuruhan Malang (2017)

Teknik sampling dalam penelitian ini adalah proportional random sampling. Dikatakan Proportional artinya teknik dalam pengambilan sampelnya harus seimbang dalam setiap strata. Random artinya pengambilan subjek secara acak, sehingga setiap subjek dianggap sama. Dimana setiap kelas dari anggota populasi dapat dipilih secara random menjadi sampel penelitian, dengan mengambil perwakilan dari setiap kelas yang dipilih secara random, yaitu dengan undian.

Berdasarkan jumlah populasi yang tergolong besar yakni sebanyak 178 mahasiswa, maka pengambilan sampel antara $10 \%-15 \%$ atau $20 \%-25 \%$ atau lebih (Arikunto, 2006). Berdasarkan pendapat diatas dapat disimpulkan bahwa sampel diambil $30 \%$ dari 178 mahasiswa yaitu 53 mahasiswa menggunakan teknik proportional random sampling. Karena subjeknya besar, maka peneliti mengambil sampel $30 \%$ dengan alasan pertimbangan keterbatasan kemampuan peneliti dari segi waktu, dana dan tenaga, besarnya sampel dalam penelitian ini dapat dilihat pada tabel berikut ini:
Tabel 2 Sampel Penelitian

\begin{tabular}{cc}
\hline $\begin{array}{c}\text { Nama } \\
\text { Sekolah/Kelas }\end{array}$ & Jumlah Sampel \\
\hline Kelas A & 10 \\
Kelas B & 10 \\
Kelas C & 11 \\
Kelas D & 11 \\
Kelas E & 11 \\
\hline Jumlah & $\mathbf{5 3}$ \\
\hline
\end{tabular}

Sumber: Data Prodi Pendidikan

Geografi Universitas Kanjuruhan Malang (2017)

Instrumen yang digunakan dalam penelitian ini yakni berupa angket. Angket merupakan lembaran yang berisi pernyataan atau pertanyaan tertulis yang digunakan untuk memperoleh informasi dari responden dengan skor yang telah ditentukan yang berkaitan dengan tingkat pengetahuan kebencanaan dan sikap kesiapsiaagaan dalam menghadapi bencana. Item angket yang digunakan sejumlah 30 pernyataan/pertanyaan yang akan disebar secara langsung pada mahasiswa Angkatan 2014 sesuai sampel penelitian. Untuk memperoleh data yang baik dan benar, maka penggunaan instrumen harus diujicobakan terlebih dahulu agar memenuhi syarat sebagai alat pengukur yang baik. Untuk mengetahui sejauh mana instrumen penelitian ini valid maka perlu dilakukan uji validitas.

Jenis intrumen yang sesuai dengan metode angket adalah angket, tabel cocok atau skala. Jenis instrumen yang digunakan dalam penelitian ini adalah angket berskala Likert dengan empat tingkatan jawaban. Tingkatan jawaban untuk intrumen adalah sangat setuju, setuju, tidak setuju dan sangat tidak setuju. Skor jawabannya dimulai dari 14 dengan skor terendah adalah 1 , dan skor tertinggi adalah 4 untuk masingmasing item. Kemudian responden 
diminta untuk memberikan tanda centang $(\sqrt{ })$ pada pilihan jawaban yang dianggap sesuai.

Teknik analisis yang digunakan dalam penelitian ini adalah deskripsi persentase. Setiap item pernyataan/pertanyaan angket diungkap dalam skor untuk selanjutnya dideskripsikan. Penelitian ini menggunakan tabel statistik yang menunjukkan angka kisaran teoritis dan rata-rata standar deviasi dengan rumus:

$$
\mathrm{DP}=\frac{\mathrm{n}}{\mathrm{N}} \mathrm{X} 100 \%
$$

Keterangan:

DP = deskriptif persentase

$\mathrm{n} \quad$ = skor yang diperoleh

$\mathrm{N} \quad=$ jumlah seluruh skor

Sumber: Riduwan (2004)

Teknik analisis deskriptif persentase digunakan untuk mengkaji tingkat pengetahuan kebencanaan dan sikap kesiapsiagaan dalam menghadapi bencana pada mahasiswa.

Tabel 3. Kriteria Deskriptif

Persentase

\begin{tabular}{cc}
\hline Skor & Kriteria \\
\hline $80-100$ & Sangat Baik \\
$60-79$ & Baik \\
$40-59$ & Cukup Baik \\
$20-39$ & Kurang Baik \\
$0-19$ & Tidak Baik \\
\hline
\end{tabular}

1. Uji hipotesis

Analisis data digunakan untuk mengetahui pengaruh tingkat pengetahuan kebencanaan terhadap sikap kesiapsiagaan dalam menghadapi bencana. Adapun analisisnya menggunakan analisis statistik dengan metode regresi linear sederhana yang bertujuan untuk mengetahui arah hubungan antara variabel independen (tingkat pengetahuan kebencanaan) dengan variabel dependen (sikap kesiapsiagaan) apakah positif atau negatif dan untuk memprediksi nilai dari variabel. Jika setelah dilakukan uji regresi linier sederhana bernilai positif berarti tingkat pengetahuan kebencanaan berpengaruh terhadap sikap kesiapsiaagan. Sebaliknya apabila bernilai negatif maka tingkat pengetahuan kebencanaan tidak berpengaruh terhadap sikap kesiapsiaagan. Penghitungan uji regresi linier sederhana menggunakan program SPSS 16.0 for Windows.

\section{HASIL DAN PEMBAHASAN}

Sebagian besar siswa memiliki pengetahuan kurang yaitu sebesar 93 siswa $(74,4 \%)$, Nilai rata rata pengetahuan siswa adalah 29,82 yang termasuk dalam kategori tingkat pengetahuan kurang. Pengetahuan merupakan hasil dari pengindraan, atau hasil tahu seseorang terhadap objek melalui indra yang dimilikinya, meliputi indra penglihatan, pendengaran, penciuman, perasa dan peraba. Terdapat beberapa faktor yang darurat dan sesudah terjadi keadaan darurat. Perencanaan kedaruratan yang baik dapat memberikan dampak yang positif pada perilaku kesiapsiagaan mahasiswa. Kemampuan mahasiswa dalam melakukan pertolongan pertama dan pengetahuan kebencanaan sangat penting dalam perencanaan kedaruratan. Mahaiswa dalam penelitian ini belum bisa melakukan kegiatan pertolongan pertama karena tidak adanya ekstrakurikuler PMR di Perguruan Tinggi. Penelitian Finnis et al (2010) yang meneliti tingkat pengetahuan, persepsi, dan aplikasi kesiapan bencana pada remaja di Taranaki, Selandia Baru, dimana pada sebaran terhadap 282 responden, dengan rentang usia 13 hingga 18 tahun, terdapat perbedaan rerata skor pengetahuan tentang 
perilaku penyelamatan diri saat bencana yang signifikan antara responden yang pernah mendapatkan pendidikan tentang bencana. Menurut Finnis, partisipasi dalam pendidikan bencana dapat meningkatkan pemahaman responden tentang perilaku melindungi diri saat bencana. Berdasarkan data yang didapatkan dari hasil wawancara bahwa pendidikan kebencanaan sering dilaksanakan ketika daerah tersebut baru saja terjadi bencana. Pendidikan kebencanaan terakhir dilakukan pada bulan Maret 2017 dan hanya diikuti lima mahasiswa sebagai perwakilan dari Perguruan Tinggi. Hanya beberapa mahasiswa saja yang bisa mengikuti pelatihan bencana sehingga informasi dari pendidikan kebencanaan belum bisa di akses oleh seluruh mahasiswa. Sebagian besar pendidikan bencana hanya akan dilakukan jika telah terjadi bencana dan berangsur semakin berkurang ketika bencana sudah lama tidak terjadi. Hal ini memungkinkan perilaku kesiapsiagaan pada komunitas yang rawan bencana akan menurun. Sebaiknya pelatihan dan pendidikan dilaksanakan secara rutin sehingga perilaku kesiapsiagaan masyarakat khususnya mahasiswa selalu berada dalam tingkat yang optimal.

\section{KESIMPULAN}

\section{Kesimpulan}

Nilai rata-rata pengetahuan mahamahasiswa adalah 29,82 dimana menurut pembagian kategori termasuk pengetahuan kurang. Tingkat pengetahuan responden dari 125 responden, sebanyak 10 responden (8\%) memiliki pengetahuan baik, 93 responden $\quad(74,4 \%) \quad$ memiliki pengetahuan kurang dan 22 responden $(17,6 \%)$ dengan pengetahuan buruk . Nilai rata-rata perilaku kesiapsiagaan mahasiswa adalah 56,15 dimana menurut pembagian kategori termasuk perilaku kesiapsiagaan hampir siap. Perilaku kesiapsiagaan mahasiswa dari 125 responden yaitu perilaku kesiapsiagaan belum siap sebanyak 12 mahasiswa $(9,6 \%)$, kurang siap sejumlah 46 mahasiswa (36,8\%), hampir siap sejumlah 38 mahasiswa $(30,4 \%)$, siap sejumlah 28 mahasiswa $(22,4 \%)$ dan sangat siap sejumlah 1 mahasiswa $(0,8 \%)$; Nilai $\mathrm{P}$ value yang didapat dari hasil uji statistik adalah $0,000<\alpha$ menunjukkan ada pengaruh atau hubungan pengetahuan dengan perilaku kesiapsiagaan terhadap bencana. Nilai $r=0,531$ menunjukkan hubungan yang kuat dan berpola positif artinya semakin bertambah pengetahuan semakin tinggi perilaku kesiapsiagaannya.

\section{Saran}

Hasil penelitian ini diharapkan dapat menambah pengetahuan dan perilaku kesiapsiagaan tentang bencana, penelitian lanjutan perlu dilakukan untuk lebih menyempurnakan pembahasan tentang masalah kurangnya pengetahuan dan perilaku kesiapsiagaan dalam menghadapi bencana. Masyarakat diharapkan dapat memberikan motivasi kepada lingkungan, kelompok, komunitas ataupun keluarga untuk dapat menghadapi bencana dan mensosialisasikan berbagai teknik alternatif untuk mengatasi masalah kesiapsiagaan dalam menghadapi bencana. Kurangnya pengetahuan masyarakat yang disebabkan oleh terbatasnya akses informasi mengenai bencana sehingga instansi pendidikan perlu terlibat dalam mensosialisasikan masalah yang terkait dengan bencana, 
sehingga pengetahuan dan perilaku kesiapsiapsiagaan masyarakat meningkat baik di komunitas maupun di perguruan tinggi.

\section{DAFTAR RUJUKAN}

Arikunto, Suharsimi. 2006. Prosedur Penelitian suatu pendekatan praktik. Jakarta: PT Rineka Cipta.

Badan Nasional Penanggulangan Bencana. (2012). Buku Saku Tanggap Tangkas Tangguh Menghadapi Bencana, Jakarta.

Bakornas-PB. 2007. Pengenalan Karakteristik Bencana dan Upaya Mitigasinya di Indonesia Edisi II. Jakarta Pusat: Direktorat Mitigasi.

BNPB. 2017. Data Kejadian Bencana 2016 , (Online), (http://dibi.bnpb.go.id/Des

Inventar/about.jsp, diakses tanggal 30 Januari 2017).

Clust, Michael, R.j. Human, dan D.M. Simpson. 2007. Mapping and Rail Safety: the Development of Mapping Display Technology for Data Communication. Center for Hazard Research and Policy Development.

Finnis, Kristen K, David M. Johston, Kevin R. Ronan, et al. 2010. Hazard Perception and Preparedness of Taranaki Youth. Disaster Prevention and Management Journal, 19, (2), 178.

Firmansyah, Imam, Hanny Rasni, dan Rondhianto. 2014. Hubungan Pengetahuan dengan Perilaku Kesiapsiagaan dalam Menghadapi Bencana Banjir dan Longsor pada Remaja Usia15-18 tahun di SMA Al-Hasan Kemiri Kecamatan Panti Kabupaten
Jember. Artikel Ilmiah Hasil Penelitian Mahasiswa. Jember: Universitas Jember.

Hammad, K.S. 2011. Emergency Nurse and Disaster Response: An Exploration of South Australian Emergency Nurses' Knowledge of Their Roles in Disaster Response. Australian Emergency Nursing Journal, 14, 4-6

Heru Susetyo. (2006). Menggagas Pendidikan Kesiapsiagaan Bencana, (Online), (http://indodisaster.multiply.com /journal/item/5, diakses tanggal 30 Januari 2017).

Hidayati, Deny, dkk. (2006). Kajian Kesiapsiagaan Bencana Masyarakat dalam Menghadapi Bencana Gempa dan Tsunami. Jakarta: LIPI-UNESCO-ISDR.

Jaelani, Achmad. (2008). Pelatihan KBBM-PERTAMA untuk KSR. Jakarta: PMI.

Motoyoshi, T. (2006). Public Perception of Flood Risk and Community-Based Disaster Preparedness. A Better Integrated Management of Disaster Risks: Toward Resilient Society to Emerging Disaster Risks in Megacities. Tokyo, Japan: Terrapub, 121-134.

Ningtyas, Bestari Ainun. 2014. Pengaruh Pengetahuan Kebencanaan terhadap Sikap Kesiapsiagaan Warga dalam Menghadapi Bencana Tanah Longsor di Desa Sridadi Kecamatan Sirampog Kabupaten Brebes Tahun 2014. Skripsi. Tidak Diterbitkan. Semarang: Universitas Negeri Semarang.

Pangesti, Asih Dwi Hayu. 2012. Gambaran Tingkat Pengetahuan 
dan Aplikasi Kesiapan Bencana pada Mahasiswa Fakultas Ilmu Keperawatan Universitas Indonesia. Skripsi. Tidak diterbitkan. Depok: Universitas Indonesia.

Pembriati, Erly Zohrian dkk. 2013. Pengaruh Model Pembelajaran Terpadu pada Pengintegrasian Materi Pengurangan Risiko Bencana dalam Mata Pelajaran IPS SMP terhadap Pengetahuan dan Kesiapsiagaan Bencana. Jurnal Bumi Lestari, Vol. 1 No.1, September 2013, hal. 1-8. Surakarta: UNS.

Riduwan. 2012. Belajar Mudah Penelitian untuk Guru Karyawan dan Peneliti Pemula. Bandung: Alfabeta.

Suparyanto. 2012.
$\begin{aligned} & \text { Kongep } \\ & \text { (http://drsuparyanto.blogspot. }\end{aligned}$
com/2012/02/konsep-

pengetahuan.html, diakses tanggal 30 Januari 2017).

Undang - undang Republik Indonesia Nomor 24 Tahun 2007 Tentang Kebencanaan.

Wahyuni, Elida dan krianto. 2011. Tingkat Pengetahuan Siswa tentang Kesiapsigaan Bencana di SMAN 1 Pariaman Sumatera Barat dan SMAN 2 Depok Jawa Barat Tahun 2011. Skripsi. Tidak Diterbitkan. Depok: Universitas Indonesia. 